\title{
Training Program for Library Technicians
}

\author{
BY BERNICE E. HEADINGS
}

IN A RECENT ARTICLE on "Personnel Shortages," Donald Strout suggested certain points to be considered in connection with the present problem of filling library positions. He stated that libraries could "Establish the importance of the clerical and his desirability over the professional in certain aspects of library operation; improve his salary structure; and develop a program of clerical recruitment." He also suggested possible utilization of professional personnel more effectively through replacement by clerical workers. ${ }^{1}$

In the last few years librarians frequently have discussed the possibility of establishing a new category of library workers, to fall between the librarian and the clerical in training, duties, and salary. Whether or not the libraries establish a separate technician level in their job classification plans, there is a need for people trained to follow the directions of the librarian in certain clerical and technical duties.

Four years ago Ferris State College, Big Rapids, Michigan, established a library technology program. Although preparations for this type of training had begun in 1958, no students were enrolled until September 1959. As stated in reports and records, there was assistance and counsel from many able librarians and close cooperation with the Michigan State library at Lansing.

Through the efforts of the college administrators and others, the plan to train technicians took the form of a two-year program. With the aid of an advisory committee made up of staff members

1 Donald F. Strout, "Personnel Shortages: The Library Profession's Number One Problem." Library Journal, LXXXVII (January 1962), 41.
Miss Headings is Director-Instructor in the Library Technician Program of Ferris State College, Big Rapids, Michigan.

from different types of libraries within the state, a curriculum was planned, leading to an Associate of Applied Science degree. The program was organized as one of the offerings of the Collegiate Technical Division of the institution and not as an adjunct to the library. At the same time there was splendid cooperation with the library.

From the first, Ferris has recognized the importance of a strong background of general education courses in the sciences, the social sciences, and the humanities. Requirements are fifty-six quarter credits in the liberal arts, sixteen in secretarial work, and twenty-one in library technology. This curriculum stresses the importance of practice work, and arrangements are made for it in the three libraries of Big Rapids: the High School library, the Big Rapids Community library, and the Ferris State College library.

Since the purpose of the courses has been to provide competent people to assist the librarian, there has been a stress upon flexible training: a background in the philosophy of library service; filing; simple reference work; routine correspondence, and following directions in simple cataloging, copying cards, circulation procedure and book ordering.

The first, basic course, Effective Use of the Library, has been built around a term paper. Using Margaret Cook's New Library Key as a textbook, the students have considered libraries as a whole, 
then the use of the Ferris State College library in particular. While the lectures have stressed the Dewey decimal system, the use of the card catalog, and reference books, the two-hour laboratory period has been devoted to the supervision of the search for materials. As students make their working bibliography on cards, they start learning the structure of the catalog card. Later they use indexes and compile a section on periodicals, followed by pamphlets, if appropriate. The note cards, the outlines, and prefaces must be approved before the paper is begun. Finally, a typed bibliography and footnotes are required. When the project is completed, the students have not only produced a theme, but have learned to use the library.

While the course in Book Selection incorporates certain basic principles in choosing books and building libraries, the emphasis has been on the activities connected with acquisition work: preparing multiple order slips and order sheets, computing prices from invoices, entering items on financial record sheets, making annotations, and performing similar duties.

The course in Reference is taught more or less in the traditional manner, with many lists of reference questions, class discussions, and at least one bibliographical assignment.

In the second year, the students take specialized courses of study such as Cataloging, Circulation, and Library Problems. They learn to copy cards and to do simple cataloging. They become familiar with registration procedures, problems connected with the care of books, handling fines, library displays, and various types of circulation systems. During this time they have experience in preparing bibliographies, writing short papers, and handling extraneous materials.

In the winter and spring sessions the students have six hours per week of practice, working under actual library condi- tions. The total number of hours of experience is approximately 120 . There has been an effort to provide a wide variety of tasks, with little duplication. The experience of assisting with acquisition work and cataloging has been provided mainly in the college library, while the inventory and shelf-reading tasks have been stressed in the other libraries. Also, the college library has provided experience in filing and circulation. While the students have had a variety of experience in all of the libraries, it is hoped that in the future it will be possible to provide more circulation experience in the public and school libraries.

During the last few years much time has been given to experimentation in teaching methods and to planning. Flexibility, it is anticipated, will continue to play an important part in the actual results of this program.

From the beginning, Ferris has faced a problem in recruitment. The Michigan State library has made a valuable contribution by offering four student scholarships per year to the new students. That agency has been active in promoting the program and has given statewide publicity to the availability of the scholarships. Both Ferris and the state library have prepared leaflets concerning the program, and particularly the scholarships.

A deterrent to higher enrollments has been the fact that there are few technician positions on existing job classification charts. Students hesitate to take the program because they are uncertain about their chances for advancement within a library, although it is of course hoped that as their availability becomes more widely known they will increasingly be called upon to fill assignments on a middle or semi-professional basis. The use of library technicians, it would seem, could do much to release professional people for tasks requiring graduate training. 